\title{
"já não será demais o que vai aqui dentro!”
}

[ "what goes in here is no longer too much"

\section{Rodrigo Jorge Ribeiro Neves ${ }^{\mathrm{I}}$}

NEVES, Rodrigo Jorge Ribeiro. “já não será demais o que vai aqui dentro!”. Revista do Instituto de Estudos Brasileiros, Brasil, n. 67, p. 263-269, ago. 2017.

DOI: http://dx.doi.org/Io.II606/issn.23I6-90IX.voi67p263-269

I Universidade de São Paulo (USP, São Paulo, SP, Brasil). 


\section{Cartas a Carlos lacerda}

Em O cartão-postal, Derrida destaca, em um dos “Envios”, a reconfiguração do sujeito no instante em que se remete/inscreve ao/no outro, em uma operação não necessariamente intercambiável, mas que é, com o perdão deste arriscado vocábulo-anátema, impossível evitar: "quando eu lhe escrevo você continua, você transfigura tudo (a transmutação vem de trás das palavras, ela opera em silêncio [...]”’2. A carta não enviada interrompe e abre um intervalo de tensões no diálogo epistolar, visto que se afasta do estabelecimento de uma correspondência. Portanto, qual é o lugar dessa carta? Como determinar a distância não percorrida? A quem se destina? A quem pertence?

Durante o desenvolvimento do projeto "Edição de texto fidedigno e anotada da correspondência de Mário de Andrade e Carlos Lacerda”, pesquisa de pós-doutorado no Instituto de Estudos Brasileiros, da USP, financiada pela Fundação de Amparo à Pesquisa do Estado de São Paulo (Fapesp), localizei duas cartas de Mário escritas para o jornalista carioca, mas não remetidas, no Arquivo do escritor, no IEB/USP. Em um primeiro momento, era possível supor que fossem rascunhos ou cópias de cartas efetivamente enviadas por Mário, algo raro em seu acervo, no entanto, pelo estabelecimento da correspondência feito até então, constata-se que Lacerda não recebeu nenhuma delas. A única carta de I942 enviada por Lacerda e recebida por Mário, ano das missivas aqui publicadas, é de 6 de fevereiro. Depois disso, o jornalista só voltaria a escrever mais de um ano depois, em II de dezembro de I943.

A primeira carta, de 28 de maio de I942, é, na sua materialidade e no seu conteúdo, irrequieta e ressentida. A caligrafia no manuscrito original é irregular e descuidada, algo atípico nos autógrafos de Mário. Ainda assim, praticamente não há rasuras. Não era apenas o avançar das horas e a possível ebriedade trazida do Franciscano, o bar-restaurante frequentado por ele e outros intelectuais na Sé, muito menos o frio glacial que costuma invadir a Pauliceia nessa temporada. O artigo "Sinceridade e poesia”, publicado por Carlos Lacerda na edição número 60 da Revista Acadêmica, de

2 DERRIDA, Jacques. O cartão-postal: de Sócrates a Freud e além. Trad. Simone Perelson; Ana Valéria Lessa. Rio de Janeiro: Civilização Brasileira, 2007, p. 206. 
maio daquele ano, desperta no escritor paulista profundas e conflituosas emoções. Se, por um lado, Mário reconhece ter lido um texto "profundamente elogioso" sobre a sua poesia e uma das "páginas mais belas, mais intensas, mais dramaticamente humanas" escritas por Lacerda, por outro, desagrada-lhe a leitura cheia de "injustiças necessárias" e o tom "impiedoso" e "cruel” do jornalista. Em carta escrita no dia seguinte a Murilo Miranda, amigo em comum dos dois missivistas, Mário ressalta que o artigo é "de uma beleza de estilo, de uma força de paixão humana, de uma eloquência verdadeira intensíssima, nada oratória, verdadeira, convincente", embora não concorde "com ele nessa atitude de seccionar assim com preto e branco" a sua poesia do resto de sua obra?

O artigo de Carlos Lacerda, cujo subtítulo é "Waldo Frank, Orson Welles, o pan-americanismo, a BBC, a guerra e a paz", parte de um programa transmitido pela rádio londrina em que seriam lidos os “Dois poemas acreanos”, de Mário de Andrade, no instante em que Lacerda estava com a reunião da obra poética do escritor paulista em mãos. Lacerda concatena a análise dos poemas com o lugar ocupado pelo poeta em tempos de guerra, de sombrias incertezas, de esperanças dilaceradas, de afetos sufocados pela atmosfera densa da destruição, não o poupando das críticas incisivas que já havia arremessado em cartas anteriores. Mário estava atravessando um período difícil, o que, provavelmente, contribuiu para acentuar sua mágoa.

Na carta seguinte, escrita quase um mês depois, Mário felicita Lacerda pelo nascimento do seu segundo filho, o editor Sebastião Lacerda, batizado com o mesmo nome do avô paterno. $\mathrm{O}$ tema da guerra volta como uma das constantes inquietações durante o período crepuscular da vida do missivista. É importante também destacar a questão de gênero presente aqui, aspecto ainda pouco explorado pela crítica sobre o modernismo brasileiro e as relações intelectuais e de poder entre seus integrantes, mas que mereceria prospectivas e cuidadosas abordagens. Em relação à discussão com Alceu Amoroso Lima na casa de Murilo Miranda, consultei pessoalmente o professor Leandro Garcia Rodrigues, estudioso da obra de Alceu, que afirmou desconhecer qualquer referência a essa polêmica nas cartas que já organizou até então. Agradeço a ele pela sua prestimosa colaboração.

Aproveito ainda a oportunidade para estender meus agradecimentos a todos os funcionários e estagiários do Arquivo do IEB, mas dedico especialmente estas cartas e apresentação a Denise Almeida, Mariana Ananias e Eduardo Sato, que gentilmente me ajudaram no processo de transcrição do texto a partir do autógrafo original, reconhecendo palavras de difícil identificação para este pesquisador. A publicação desta documentação também se deve muito ao profissionalismo exemplar, ao exímio conhecimento técnico e à atenção abnegada e afetuosa desses e de todos os demais profissionais do Arquivo.

3 ANDRADE, Mário de. Cartas a Murilo Miranda (I934-I945). Ed. prep. por Raúl Antelo. Rio de Janeiro: Nova Fronteira, I98I, p. II2. 
São Paulo, 28 de maio de I942.

Meu Carlos,

não posso! Eu tenho mesmo que largar de tudo (este capítulo sobre arte inglesa, que martírio!), pra escrever a você imediatamente. Recebi ao meio-dia a Rev. Acadêmica e reli seu artigo sobre mim. Eu tinha lido ele aí no Rio que o Murilo me mostrou. Mas então eu estava bem acolchoado, amigos, chope, felicidade, e aguentei bem. Mas hoje, li, e o seu artigo me comoveu extraordinariamente. Cheguei a sentir um gosto de lágrima e parei comigo. $\mathrm{Me}$ meti logo continuando esta arte inglesa, a coisa roncando por dentro, só às 23 horas fui no Franciscano, que não me aguentava mais, mas levando a Acadêmica debaixo do braço, neste frio que não deixa mão fora de bolso. Bebi que mais bebi, resolvi que só escreveria a você, já me acalmado, só na semana que vem. Mas chego em casa, são três horas e é isto: não posso mesmo sem lhe escrever já.

Bom, já quando lera o artigo de você aí no Rio, ressalvara a interpretação falsa, mesmo injusta que você fizera dos meus versos de "Manhã", quando eu invoco Lenine, Carlos Prestes, Gandhi, peço que "se assentem um bocadinho" pra eu deixar "um disfarce de festa" neles. Não é possível você perceber "gratuidade” nisso, Carlos. É apenas uma carícia humana a homens escolhidos, estimados, como você encontrando um "homem bom" que faz dois dias não dorme no seu trabalho, você dará seu ombro, o ombro que foda-se se doer, pra o homem bom descansar. Não é possível imaginar que eu quisesse tirar Lenine ou Gandhi de seus caminhos humanos, fazendo eles caírem na farra eterna! Quis lhes dar um "disfarce de festa” onde recobrassem mais forças pra cumprir seus destinos enormes. Qualquer interpretação diferente não chega a ser injusta, é pueril.

Bom, mas eu sabia que se, no momento, você interpretava assim meus versos é porque isso servia. Achei que estava certo. O seu artigo, eu sei, é profundamente elogioso, mas está cheio também dessas injustiças necessárias. E que eu servisse a você pra tirar lutas maiores que nós, lhe juro que isso me enche de dignidade. Eu me presto muito bem e me gosto de me prestar para as coisas necessárias que você quis dizer. E ainda me comoveu muito ter sido o motivo para uma das páginas mais belas, mais intensas, mais dramaticamente humanas que você já escreveu. Realmente você consegue por vezes uma força, uma paixão de participação social lancinante, é convincente. Há por todo o artigo uma eloquência verdadeira, sem a menor sombra de demagogia, dessa eloquência que nasce mesmo do ímpeto da verdade e do desespero do coração.

Mas até fica grã-fino, fica "estético" estar assim constatando a beleza dramática, admiravelmente bem escrita do artigo, como se a gente estivesse no ano dois mil conversando calminho, numa sociedade já assentada, sobre a concepção sthendaliana da fornicação. Não. Eu participo integralmente, apaixonadamente da paixão de você e só exalto o que você escreveu porque é grito, é pranto de vida humana.

Mas não posso deixar de sofrer porque você foi cruelmente injusto comigo por causa... dos outros. Por causa de todos?... É injusta a insistência de você sobre as minhas "safadezas", sobre as minhas "indecisões", sobre as minhas "puerilidades”, etc. Aí é que eu me separo de você.

Não tem dúvida que ainda aí eu compreendo você. É sempre uma homenagem, é ainda um elogio e dos enormes. Se você tem de atacar um mundo errado, é forte que você ataque o Serviço do Patrimônio ou eu. Você não ataca, não perde tempo em atacar o Instituto do 
Livro nem o Cassiano Ricardo que se esboroam por si mesmos, mas você ataca entidades e seres que se sustentam, que valem.

Mas o que eu sofro, Carlos, meu Carlos, é que eu me pergunto até que ponto a noção moral de verdade permite a você dizer certas, nem sei como chamar, certas inverdades. Até que ponto você pode esculhambar a grandeza de um futuro humano, sacrificando a noção da verdade e do bem, pragmaticamente. Não é uma imoralização do seu, de você, próprio ser e da verdade que você representa, do futuro que você representa?

Vejamos: você desnuda as minhas "indecisões”, que indecisões? Quando a minha vida humana vai se processando num completamento, lento eu sei, mais gradativo de acrescentamento humano? Isso ainda pode ser uma atitude pragmática e não fere muito, mas me parece que você foi um bocado impiedoso para o meu silêncio, para a minha dúvida (não é possível esquecer que eu não tenho certeza, venho de um mundo que não me dá certeza, essa certeza que tantos proclamam de boca pra fora, prontos a recusá-la ao primeiro segundo de utilitarismo pessoal), você foi impiedoso para com o meu drama que você conhece, me fazendo assim de bode expiatório das indecisões e das "safadezas"... dos outros! "Safadeza", eu! Aí você foi mais que impiedoso, foi cruel, Carlos. E todo o meu dia isto me passou roncando e é a razão única de eu estar escrevendo já. Não faz mal eu sofrer, prefiro você impiedoso porque eu necessito saber. O horrível é esta traição até das cartas da gente imaginar que os outros pensarão que se está posando pro futuro. Eu lhe peço, suplico pelo que você tem de mais digno e resguarda mais em si mesmo que você rasgue esta carta mas eu careço saber que ato meu, que palavra você considera safadeza. Seja mais cruel, se possível, mas diga, que essa ideia de praticar safadeza me horroriza.

Eu não sou melhor que os outros, mas do fundo familial e moral de que eu vim, posso ser um pouco diferente de muitos. Eu ainda venho daquela noção católica da culpa que exige a retratação no reconhecimento da culpa. Eu não posso ter a consciência de uma safadeza minha sem procurar me consertar, palavra que não posso. Eu tenho errado muito, tenho sido muito ineficaz botando o imediatismo do útil onde ele não era imediato. Mas também no dia em que eu pretendi confessar isso em público no Testamento da minha geração, você foi dos que me impediram de publicar minha verdade atual. Depois disso ninguém imagina como eu tenho me debatido, numa ânsia danada de me acertar. $E$ a gente, a vida corre, tem a tendência natural pra esquecer os inícios da vida. Eu me lembro, não sei se você lembra, uma das primeiras cartas minhas, talvez a primeira de já entrados no terreno da camaradagem, carta inesquecível pelo custo que me deu de confessar lealmente a você que eu não poderia corresponder às esperanças e exigências de você, moço de outra idade e ideias e confessava ser um indivíduo que não tinha certeza, que acreditava em Deus, que por mais próximo de você em conclusões simplesmente humanas, estava inexoravelmente separado de você em possíveis conclusões políticas.

Carlos, meu Carlos e Carlos meu, vamos parar, agora não posso mais mesmo, não posso de não posso, são quatro horas. Eu estou sacudindo você pelos ombros, com brutalidade de bem-querer. Carlos, acorda! Acorda por favor! Eu não quero mudar você um passo, um milímetro do seu caminho. Se eu não tenho a certeza do meu! E me envergonho de não ter certeza! E se eu não posso deixar de ser um homem que veio do século das luzes, do século que tinha certeza! Se eu adoro, amo a certeza e não posso largar o meu desejo de certeza!...

Nos acalmemos. Não para a vida dessa vida humana, mas pra com o dentro de nós. Eu tenho que insistir, embora nisto talvez eu é que esteja sendo cruel. Mas eu preciso que você 
me conte no que eu fui safado, as safadezas que eu pratiquei. Pra me penitenciar. O que que eu posso comigo mais que não ser aquele individualista? Meus versos, meus estudos e atos, minha honestidade pública, meu pragmatismo, uma merda. Meu amor desinteressado dos homens, da realização humana, sim, possivelmente uma dignidade. A realização moral pública e humana do meu ser, isso é uma exigência imprescindível. Só o controle disso, eu posso exigir de você que é dos meus amigos. Estou chorando, Carlos. Vou fechar esta carta já, nem releio. Vou mandar sem pensar. Já não será demais o que vai aqui dentro! O resto é o homem com o seu mistério.

Carta datada: “São Paulo, 28-V-42”, autógrafo a tinta preta; papel branco, filigrana; 3 folhas; 26,2 x 20,6 cm; borda superior irregular. (Arquivo Mário de Andrade, IEB-USP).

São Paulo, 26 de junho de I942.

Carlos.

Quis lhe telegrafar, telefonar, não sei, fiquei tão assanhado, ainda me surpreende o milagre da criação. Deve de ser extasiante ter um filho... Depois imaginei que o telegrama não achando você nem Ziloca em casa, iria deixar um recadinho apenas por baixo da porta, "Procure telegrama na Central”. E você teria que ir até lá pra receber mais um abraço e apenas. A prática telegráfica é esta aí no Rio, como é em São Paulo? Resolvi lhe escrever carta mais recebível sem chateação.

O mesmo que diria no telegrama é o abraço carinhoso e muito verdadeiro que vai aqui pra você com Ziloca. (Que dianho! Me esqueci de saber como se escreve o $Z$ de Ziloca. Também são duas e meia da manhã...). O mesmo abraço e mais o desejo que Deus proteja o machinho novo. O machinho novo... Me contaram que vocês desejavam mulher... Não sei, pode ser o problema "estético" de criar um casal. Mas eu, solteirão insolúvel, o "Solteirão Impossível" ou "Ausente" como diriam os da escola poética do Augusto Frederico Schmidt, sempre que minha irmã está pra ter filho, também desejo mulher. Há-de haver, é necessário haver, nisto, uma desistência covarde diante do mundo contemporâneo... A vida prá mulher foi sempre mais difícil, mas nos momentos de agora a vida do homem se tornou mais difícil. Carne pra canhão, Gestapos e sobretudo a interrogação dolorosíssima "E agora, o que fazer?" como no livro do Batini. A mulher, pelo menos, está com os gestos mais livres e vem atrás. Quase sempre, vem atrás...

Bem, não vale a pena recordar - e quanto me impressionou! - a sua discussão com o Alceu na casa do Murilo. Você quase integralmente esteve com a razão, me parece, mas fundamental, essencialmente, digamos mais uma vez "funcionalmente", o Alceu talvez estivesse com a razão. $O$ pivot do problema - uma questão de atitude ativa - é o mesmo que me tem feito discutir noites e cartas com amigos mais moços. Mas agora decidi não discutir mais. É sempre odioso mandar que os outros se sacrifiquem e sofram, a gente se escondendo atrás da própria idade pra não ir pra guerra mais, nem se sacrificar. E sofrer apenas de reflexo. Resolvi não discutir mais.

Assim, o que que eu posso desejar mais pro machinho novo senão aquilo que eu desejava ter pro meu coração? Um mundo nítido, Carlos, um mundo preto ou branco. O ideal seria um mundo só branco, mas isso eu desconfio que jamais virá pra humanidade. Pelo menos 
enquanto viva... Mas imagina só, meu Carlos, um mundo só preto e branco, em que não haja indecisões nem temores de engano, em que ninguém cruze os braços à espera que os sucessos decidam nosso primeiro gesto! É sempre uma espécie de felicidade, quando as outras se tornam mitos inatingíveis.

Não tenho, não posso ter a leviandade de escrever desejando todas as felicidades (prazeres) pro machinho novo. Eu imagino que você está num segundo extasiante de sua vida que talvez eu vá quebrar. Assim, esta carta não irá antes da segunda-feira, mesmo porque meu secretário fidelíssimo só a porá, no mais próximo, domingo no correio. Por isso posso bem pôr aqui meus desejos de que seu filho seja de um tempo nítido, um homem nítido, dum tempo solucionado. Que ainda seja de guerra? Não faz mal, meu Deus! Mas de um tempo mais nítido, bem nítido, bem solucionado, oito ou oitenta, preto ou branco, em que cada gesto humano se confunda com a honestidade interior. Será tão lindo!... Tão claro!...

Com o abraço melhor do

Mário

Carta datada: “São Paulo, 26-VI-42.”; autógrafo a tinta preta; papel branco, filigrana; I folha; 26,1 x 20,5 cm. (Arquivo Mário de Andrade, IEB-USP).

SOBRE O AUTOR

RODRIGO JORGE RIBEIRO NEVES é pesquisador de pós-doutorado no Instituto de Estudos Brasileiros (IEB/USP) e bolsista Fapesp, com o projeto "Edição de texto fidedigno e anotada da correspondência de Mário de Andrade e Carlos Lacerda”. Foi pesquisador da Fundação Casa de Rui Barbosa e pesquisadorvisitante da Universidade de Princeton.

E-mail: rodrigorirn@gmail.com

\section{REFERÊNCIAS BIBLIOGRÁFICAS}

ANDRADE, Mário de. Cartas a Murilo Miranda (I934-I945). Ed. prep. por Raúl Antelo. Rio de Janeiro: Nova Fronteira, I98I.

DERRIDA, Jacques. O cartão-postal: de Sócrates a Freud e além. Trad. Simone Perelson; Ana Valéria Lessa. Rio de Janeiro: Civilização Brasileira, 2007. 